KS. PAWEŁ KALETA

Wydział Prawa, Prawa Kanonicznego i Administracji

Katolickiego Uniwersytetu Lubelskiego Jana Pawła II

\title{
WYTYCZNE STOLICY APOSTOLSKIEJ \\ DOTYCZĄCE ZARZĄDZANIA DOBRAMI \\ W INSTYTUTACH ŻYCIA KONSEKROWANEGO \\ I W STOWARZYSZENIACH ŻYCIA \\ APOSTOLSKIEGO
}

Treść: Wstęp. - 1. Zarządzanie dobrami. - 1.1. Charyzmat, misja, dzieła i planowanie. - 1.2. Transparentność i nadzór - gwarancją prawidłowości. 1.3. Sprawozdania i bilanse. - 1.4. Zarządzanie majątkiem a patrimonium stabile. - 2. Współpraca z Kościołem lokalnym, z innymi instytutami i konsultantami. - 3. Formacja w wymiarze ekonomicznym. - Wnioski.

Dnia 2 sierpnia 2014 r. Kongregacja ds. Instytutów Życia Konsekrowanego i Stowarzyszeń Życia Apostolskiego wydała pismo okólne pt. Wytyczne dotyczace zarządzania dobrami $w$ instytutach życia konsekrowanego i stowarzyszeniach życia apostolskiego ${ }^{1}$. Inicjatywą wydania listu okólnego przez wspomnianą Kongregację ${ }^{2}$ było sympozjum,

\footnotetext{
${ }^{1}$ Congregazione per gli Istituti di Vita Consacrata e le Società di Vita Apostolica, Lettera Circolare - Linee orientative per la gestione dei beni negli Istituti di vita consacrata e nelle Società di vita apostolica, Libreria Editrice Vaticana, 2014. Tekst w jęz. polskim, Konferencja Wyższych Przełożonych Zakonów Męskich w Polsce http://www.zyciezakonne.pl/2014-08-02-list-okolny-wytyczne-dotyczace-zarzadzania-dobrami-w-instytutach-zycia-konsekrowanego-i-stowarzyszeniach-zycia-apostolskiego-45437/ [dostęp 02.06.2017].

${ }^{2}$ Termin „Kongregacja” w tekście jest zastosowanym skrótem i dotyczy Kongregacji ds. Instytutów Życia Konsekrowanego i Stowarzyszeń Życia Apostolskiego.
} 
które odbyło się na Papieskim Uniwersytecie Antonianum w Rzymie pod nieco innym tytułem: Zarzad dobrami kościelnymi instytutów $\dot{z} y c i a$ konsekrowanego i stowarzyszeń życia apostolskiego w stużbie »humanum $i$ misji w Kościele.

Wydanie wspomnianych wytycznych jest potrzebą czasu, może stanowić pomoc dla tych, którzy na co dzień stoją przed nowymi wyzwaniami związanymi z zarządzaniem dobrami instytutu zakonnego lub stowarzyszenia życia apostolskiego. Chociaż, zasadnicza treść dokumentu dotyczy przełożonych zakonnych i ekonomów, to jednak z niego mogą korzystać wszyscy członkowie instytutów, którzy zarządzają dobrami kościelnymi należącymi do instytutu.

Celem niniejszego przedłożenia jest ukazanie nowego dokumentu normatywnego, który dotyczy zarządzania dobrami w instytutach życia konsekrowanego i stowarzyszeniach życia apostolskiego. Warto dodać, że również Kongregacja określiła cel listu okólnego ma on ułatwić pełnienie odpowiedzialnych funkcji w różnych rodzinach zakonnych.

Układ listu okólnego jest następujący: Wstęp; Rozdział I - Zarządzanie dobrami; Rozdział II - Współpraca z Kościołem lokalnym, $\mathrm{z}$ innymi instytutami i konsultantami; Rozdział III - Formacja w wymiarze ekonomicznym.

Układ treści artykułu został przyjęty według schematu referowanego listu okólnego.

\section{Wstęp}

Kongregacja we wstępie listu okólnego potwierdza normę prawną zawartą w kan. $635 \$ 1^{3}$, która dotyczy, że dobra materialne instytutów życia konsekrowanego i stowarzyszeń życia apostolskiego są dobrami kościelnymi. Instytuty, będąc publicznymi osobami prawnymi w Kościele (kan. 1257 \$1) wykonują swoje zadania w imieniu Kościoła (kan.

\footnotetext{
${ }^{3}$ Kan. dotyczy Codex IURIs Canonici auctoritate Ioannis Pauli PP. II promulgatus, AAS 75 (1983), II, pp. 1-317; Kodeks Prawa Kanonicznego, przekład polski zatwierdzony przez Konferencję Episkopatu, Poznań 1984.
} 
$116 \$ 1$ ). Dlatego konieczność używania dóbr materialnych „nie powinna nigdy zapanować nad samym »celem«, któremu mają służyć, i z którego powinno wypływać ich ograniczenie, szlachetność zadania i znaczenie duchowe" 4 .

W liście okólnym podkreślono, że wymiar ekonomiczny jest nierozerwalnie związany z osobą prawną i misją instytutu ${ }^{5}$. Ekonomia determinuje bardzo ważne dla życia decyzje, z których powinno wynikać świadectwo ewangeliczne. Dlatego wymiar ekonomiczny nie powinien być pomijany w procesie formacyjnym, zwłaszcza w przygotowaniu tych, którzy będą sprawować odpowiedzialne funkcje w zarządzie dobrami instytutu (por. Dz 4, 32-35).

\section{Zarządzanie dobrami}

Treść rozdziału pierwszego dotyczy wybranych zagadnień z dziedziny zarządzania dobrami w instytutach życia konsekrowanego i stowarzyszeniach życia apostolskiego. Wśród aspektów zarządzania Kongregacja wyodrębnia następujące:

1) Charyzmat, misja, dzieła i planowanie;

2) Transparentność i nadzór - gwarancją prawidłowości;

3) Sprawozdania i bilanse;

4) Zarządzanie majątkiem a patrimonium stabile.

1.1. Charyzmat, misja, dzieła i planowanie

Kongregacja przypomina, że wierność charyzmatowi założycielskiemu oraz ukształtowanemu przez ten charyzmat duchowemu dziedzictwu każdego instytutu ${ }^{6}$ wraz z wymaganiami ewangelicznymi

\footnotetext{
${ }^{4}$ Bł. PAwEŁ VI, Rozważanie w czasie audiencji generalnej, 24 czerwca 1970, http://www. opoka.org.pl/biblioteka/W/WP/pawel_vi/audiencje/ag_24061970.html [dostęp 03.06.2017].

${ }^{5} \mathrm{~W}$ tekście autor posłużył się skrótem „instytuty”, mając na myśli zarówno instytuty życia konsekrowanego, jak i stowarzyszenia życia apostolskiego, do których adresowany jest list okólny.

${ }^{6}$ Johnnes Paulus PP, Adhortatio Apostolica Postsynodalis de vita consecrata eiusque missione in Ecclesia ac mundo Vita consecrata, 25 III 1996, AAS 88 (1996), pp. 377-486; tekst polski w: Posynodalna adhortacja apostolska „Vita consecrata” Ojca Świętego Jana Pawła II do biskupów i duchowieństwa, do zakonów i zgromadzeń
} 
stanowi pierwsze kryterium oceny dotyczącej decyzji związanych z zarządzaniem dobrami instytutu. Kryterium wierności charyzmatowi odnosi się do każdego poziomu zarządzania, jako że „charyzmat kieruje wykorzystaniem energii, umacnia wierność i nadaje kierunek pracy apostolskiej wszystkim, zwracając ją ku wspólnej misji”" . Kongregacja uważa za niezbędne odczytanie na nowo zgodności misji z charyzmatem. Przy czym należy sprawdzić, czy tożsamość z charyzmatem zakonnym znajduje odzwierciedlenie w charakterystycznych działaniach praktycznych. Może bowiem zdarzyć się, że dzieła instytutu nie są już odpowiednie do aktualnego charakteru misji, a zarządzane nieruchomościami tracą swą funkcjonalność dla dzieł wyrażających dany charyzmat ${ }^{8}$. W związku z tym konieczne jest:

a) Ustalić, które dzieła i rodzaje działalności należy kontynuować, których należy zaprzestać, które zmodyfikować i ku jakim nowym obszarom kierować projekty rozwoju i świadectwa misji, tak aby odpowiadały dzisiejszym potrzebom, dochowując całkowitej wierności własnemu charyzmatowi.

b) Wdrożyć procedury, które umożliwią dobre planowanie zasobów, przewidując wykorzystanie budżetu oraz preliminarzy budżetowych, sprawdzanie i korygowanie ewentualnych niezgodności, kontrolę zarządzania, uważne śledzenie sprawozdań finansowych, weryfikację i w miarę potrzeby zmianę przyszłych działań; takie procedury są niezbędne zarówno do inicjowania nowych dzieł, jak i do podejmowania rozważnych decyzji w razie likwidacji lub alienacji nieruchomości.

zakonnych, do wszystkich wiernych o życiu konsekrowanym i jego misji w Kościele i świecie, Wrocław 1999.

${ }^{7}$ Francis Pope, Message of Pope Francis to participants in the international symposium on the management of ecclesiastical goods, Pontifical Antonianum University , 8-9 March 2014, https://w2.vatican.va/content/francesco/en/messages/pont-messages/2014/documents/papa-francesco_20140308_messaggio-vita-apostolica. html [dostęp 04.06.2017].

${ }^{8}$ Zob. F. MARINI, Gli istituti secolari: amministrazione dei beni temporali e personalità giuridica (can. 718), Quaderni di Diritto Ecclesiale 20 (2007), s. 402-414. 
c) Opracować długoterminowe plany i prognozy, by jak najskuteczniej zapobiegać powstawaniu problemów lub stawić im czoło, dopóki sytuacja jest jeszcze możliwa do opanowania.

d) Skorzystać z preliminarza budżetowego nie tylko dla dzieł instytutu, ale także w poszczególnych wspólnotach, jako narzędzia formacji w wymiarze ekonomicznym, mającej służyć wzrostowi świadomości wspólnej w tym obszarze oraz weryfikacji rzeczywistego stopnia ubóstwa osobistego oraz wspólnotowego.

e) Wprowadzić odpowiednie systemy monitorowania dzieł podupadających, wdrażać plany wychodzenia z deficytu i należy przezwyciężać mentalność opiekuńczą instytutu: poprzez pokrywanie strat danego dzieła bez rozwiązania problemów związanych z jego zarządzaniem.

f) Zwrócić uwagę na stabilność dzieł (pod względem duchowym, relacji w nich panujących i ekonomicznym), w przypadku wątpliwości należy dokonać rewizji podjętych dzieł.

g) Stworzyć, jeśli jest to konieczne, nowe struktury, które będą łatwe w zarządzaniu, a w sytuacji deficytu powołań zakonnych łatwo zbywalne lub nadające się do częściowego użytkowania bez ponoszenia wysokich kosztów.

\subsection{Transparentność i nadzór - gwarancją prawidłowości}

Kongregacja podkreśla, że bycie świadkiem Ewangelii wymaga, aby dzieła instytutu były wykonywane z zachowaniem pełnej przejrzystości, z przestrzeganiem zarówno prawa kanonicznego, jak i państwowego. Transparentność finansów ${ }^{9}$ ma kluczowe znaczenie dla efektywności i skuteczności prowadzenia misji instytutu zakonnego ${ }^{10}$. Tuszowanie niegospodarności lub nieudolności w zarządzaniu

\footnotetext{
${ }^{9}$ Przykładem transparentności finansów może być dokument Zakonu Braci Mniejszych, Franciszkańskie zarządzanie finansami. Subsydium Definitorium Generalnego dla formacji do przejrzystego, solidarnego i etycznego używania naszych zasobów ekonomicznych, http://www.ofm.org/documentsOFM/Sussidio_Economia_PL.pdf [dostęp 01.06.2017].

${ }^{10}$ Zob. A. PerlascA, Istituti religiosi e amministrazione dei beni temporali, w: Novità e tradizione nella vita consacrata. Riflessioni teologiche e prospettive
} 
nie służy wiarygodności, lecz pokazuje niedojrzałość tych, którzy zgadzają się „na zamiatanie spraw pod dywan”. Dlatego każde sprawozdanie finansowe powinno odzwierciedlać postulat przejrzystości finansowej. Kongregacja odwołała się do słów bł. Pawła VI, który dzień po zakończeniu Soboru Watykańskiego II, wezwał do „nowej, autentycznej mentalności chrześcijańskiej” i „nowego stylu życia kościelnego"11.

Transparentność finansów powinna mieć również swoje odzwierciedlenie w nadzorowaniu zarządu dobrami. Kongregacja wyjaśnia, że władza nadzoru nie może być odczytywana jako ograniczenie munus regendi lub brak zaufania wyższych przełożonych wobec podmiotów im podległych. Prawo do nadzorowania powinno być interpretowane jako środek troski o to, aby do zarządzania nie wkradły się nadużycia ${ }^{12}$. Ponadto, nadzór ma służyć budowaniu komunii na rzecz przejrzystości.

W praktyce, władza nadzorcza ma uwzględniać nie tylko przepisy prawa powszechnego, ale również przepisy prawa własnego instytutu. Dla osiągnięcia tych celów przełożeni wyżsi wraz ze swymi radami powinni:

a) Opracować odpowiednie systemy kontroli wewnętrznej, dostosowane do rozmiarów dzieł, w oparciu o odpowiedni podział obowiązków i jasny system zezwoleń.

b) Upewnić się, czy realizowanie misji przy użyciu dóbr doczesnych przebiega w poszanowaniu zasad ewangelicznych, a jednocześnie uwzględnia opłacalność ekonomiczną.

giuridiche, red. S. Recchi, Milan 2004; Y. Sugwara, Amministrazione e alienazione dei beni temporali degli istituti religiosi nel Codice, Periodica 97 (2008), s. 251-282.

${ }^{11}$ B£. PAweŁ VI, Audiencja General Audience, 24 czerwca 1970, L’Osservatore Romano, edycja angielska, 2 lipca 1970, s. 3.

${ }^{12}$ Por. A. Chrapkowski, J. Krzywda, Dobra doczesne i ich zarząd, w: Komentarz do Kodeksu Prawa Kanonicznego vol. II/2. Księga II Lud Boży. Część III. Instytuty życia konsekrowanego i stowarzyszenia życia apostolskiego, red. J. Krukowski, Poznań 2006, s. 69. 
c) Mieć jasny obraz tego, jak są zarządzane poszczególne dzieła w obrębie każdej prowincji, zarówno te, które są własnością danego instytutu, jak i te przez niego promowane lub wyodrębnione $\mathrm{z}$ instytutu (np. fundacje lub stowarzyszenia).

d) Zatwierdzać plany inwestycyjne i budżety na początku roku; wymagać właściwej dokumentacji i rejestrowania operacji różnego rodzaju ${ }^{13}$.

e) Prawodawca kościelny na mocy kan. $636 \$ 1$ zobowiązuje wyższego przełożonego instytutu zakonnego do ustanowienia na czas określony ${ }^{14}$ ekonoma instytutu. Podobnie ma uczynić przełożony domu zakonnego ${ }^{15}$. Zadaniem ekonoma instytutu jest zarządzanie dobrami instytutu zakonnego pod kierownictwem przełożonego. Kongregacja w liście okólnym wymienia następujące zadania ekonoma:

- Przedstawiać przełożonym wyższym i ich radom okresowe sprawozdanie dotyczące funkcjonowania administracji, zarządzania i finansów instytutu lub prowincji, lub pojedynczego dzieła (zob. kan. $635 \$ 2$ ).

- Dokumentować transakcje i umowy w sposób zgodny z wymogami prawodawstwa cywilnego obowiązującego w odnośnych miejscach.

- Stosować współczesne systemy archiwizacji danych.

\subsection{Sprawozdania ${ }^{16}$ i bilanse}

Istotną cechą sprawozdań finansowych jest ukazanie stanu ekonomicznego instytutu. W tym, podstawowe znaczenie mają odpowiednie

\footnotetext{
${ }^{13}$ Zob. R. Smith, The Governance of Institutes, w: New Commentary on the Code of Canon Law, red. J.P. Beal, J.A. Corriden, T.J. Green, New York 2000, s. 805.

${ }^{14}$ Okres trwania kadencji ekonoma określa prawo własne instytutu zakonnego (kan. $636 \$ 2$ ).

${ }^{15}$ Zob. D.J. Andrés, El derecho de los religiosos. Comentario al Código, Madrid 19854, s. 209.

${ }^{16}$ Papież Franciszek w swoim liście do uczestników sympozjum poświęconego zarządzaniu finansami w instytutach zakonnych połączył wymiar ekonomiczny instytutu z jego charyzmatem i uznał, że ma to stać się humus w tradycji administracyjnej
} 
zasady sporządzania bilansów i sprawozdań. Szczególnie znaczenie ma praktyka oddzielania budżetów dzieł, od budżetów wspólnot. List okólny stanowi, że określenie wspólnych zasad rachunkowości oraz wzorów bilansów dla wszystkich podmiotów w obrębie jest konieczne do ujednolicenia procedur sporządzania samych bilansów na szczeblu krajowym i międzynarodowym. W tym zakresie instytuty życia konsekrowanego i stowarzyszenia życia apostolskiego powinny:

a) Sporządzać bilanse według jednolitych wzorów międzynarodowych, wprowadzając zasady rachunkowości, wzorce sprawozdawczości i kryteria oceny pozycji w bilansie wspólne na szczeblu krajowym i międzynarodowym.

b) Wprowadzić dla dzieł certyfikację bilansów i tzw. audyty, będące ze strony instytutów gwarancją prawidłowości pod względem ekonomiczno-administracyjnym;

c) Zasięgać rady wykwalifikowanych ekspertów, obeznanych z charakterem posługi Kościoła, a także nauczycieli akademickich, czy to z uniwersytetów katolickich, czy z innych uczelni. Uzyskanie transparencji i wiarygodności sprawozdań dotyczących majątków oraz zarządzania może być znacznie łatwiejsze, gdy korzysta się z pomocy ekspertów, gwarantuje to bowiem przyjęcie właściwych procedur, z uwzględnieniem rozmiarów instytutu i jego dzieł.

W liście okólnym podkreślono, że w przypadku braku certyfikowanych bilansów Kongregacja ds. Instytutów Życia Konsekrowanego i Stowarzyszeń Życia Apostolskiego może odmówić zatwierdzenia procedur finansowania.

instytutów, która nie może tolerować marnotrawienia dóbr oraz zwrócił uwagę na dobre wykorzystanie zasobów. List do uczestników międzynarodowego sympozjum na temat Zarządzanie majątkami kościoła instytutów życia konsekrowanego i stowarzyszeń życia apostolskiego w służbie człowiekowi i misji Kościoła. 08.03.2014. Treść listu dostępna w jęz. angielskim: Pope Francis, Message of Pope Francis to Participants in the International Symposium on the Management of Ecclesiastical Goods, Pontifical Antonianum University, 8-9 March 2014, https://w2.vatican.va/content/ francesco/en/messages/pont-messages/2014/documents/papa-francesco_20140308_ messaggio-vita-apostolica.html [dostęp 04.06.2017]. 


\subsection{Zarządzanie majątkiem a patrimonium stabile}

Patrimonium stabile jest pojęciem stosunkowo nowym. Rozumie się przez nie zarówno dobra ruchome, jak i nieruchome, dobra materialne i niematerialne, które ze swej natury lub przez wyraźne określenie zostały przeznaczone dla utrzymania kościelnej osoby prawnej ${ }^{17}$. Patrimonium stabile jest przeciwieństwem do wolnego lub płynnego kapitału, który ma być stosowany w celu pokrycia bieżących wydatków. Patrimonium stabile nie należy narażać na ryzyko utraty. Nie ma jednak absolutnych zasad dla ustanowienia majątku stałego, ponieważ to zależy nie tylko od natury i właściwości dóbr, ale także od finansowych wymagań, aby kościelna osoba prawna mogła realizować cele, dla których została ustanowiona ${ }^{18}$.

Rozróżnienie patrimonium stabile od innych dóbr kościelnych jest istotne, bowiem dobra doczesne, które nie należą do patrimonium stabile, nie podlegają przepisom o alienacji ${ }^{19}$. Nie oznacza to jednak, że zarządcy są wolni w dokonywaniu czynności prawnych na majątku innym niż patrimonium stabile. Dobra takie nadal są dobrami kościelnymi i podlegają przepisom prawnym o zarządzaniu. W szczególności dotyczy to aktów nadzwyczajnego zarządzania, aby ich dokonać, zarządca zobowiązany jest uzyskać zgodę ordynariusza, a ten zgodę

\footnotetext{
${ }^{17}$ P. Kaleta, Pojęcie "patrimonium stabile«, Roczniki Nauk Prawnych 24 (2014) nr 4, s. 147-161.

${ }^{18}$ M. López Alarcón, Book V. Temporal Goods of the Church, w: Code of Canon Law Annoted, red. E. Caparros, H. Anbé, Montreal 20042, s. 993; V. DE PAolis, De bonis Ecclesiae temporalibus, s. 145; tenże, Los bienes temporales de la Iglesia, Madrid 2012, s. 256; F. GrazIAn, Patrimonio stabile. Istituto dimenticato?, Quaderni di Diritto Ecclesiale 16 (2003), s. 282-296; J.P. Schouppe, Derecho patrimonial canónico, Pamplona 2007, s. 155-157.

${ }^{19}$ Znamienne jest, że kan. $638 \$ 3$ nie odnosi się do dóbr określonych mianem patrimonium stabile jak ma to miejsce w kan. 1291. Do ważności dokonania aktów alienacji wymagane jest pisemne zezwolenie kompetentnego przełożonego, które zostało wydane za zgodą jego rady. P. Kaleta, Ecclesiastical patrimonial law, Manchester 2015, s. 227. J.A. Renken, Church Property. A Commentary on Canon Law Governing temporal Goods in the United States and Canada, Ottawa 2009, s. 258.
} 
diecezjalnej rady do spraw ekonomicznych i kolegium konsultorów (kan. $1281 \$ 1 ; 1277)^{20}$.

Kongregacja w liście okólnym postuluje, aby każdy instytut życia konsekrowanego i stowarzyszenie życia apostolskiego, po dokonaniu starannej oceny całościowego obrazu oraz odnośnych dzieł, wydały listę dóbr stanowiących patrimonium stabile, $\mathrm{z}$ odniesieniem również do prawodawstwa cywilnego. Natomiast przełożony wyższy ze swoją radą powinien zatwierdzić je na mocy uchwały. Obligatoryjność wprowadzenia pojęcia patrimonium stabile powinna być potwierdzona w konstytucjach albo przynajmniej w innym dokumencie będącym zapisem prawa własnego instytutu.

\section{Współpraca z Kościołem lokalnym, $z$ innymi instytutami i konsultantami}

Drugi rozdział listu okólnego Kongregacja poświęca współpracy z Kościołem lokalnym i z innymi instytutami i z konsultantami. Referowany dokument stanowi, że misja instytutów zakonnych ma wymiar uniwersalny a w przypadku wielu instytutów obejmuje cały świat. Instytuty działając w świecie są jednocześnie osadzone w specyficznych realiach Kościoła lokalnego. Stąd instytuty powinny być w stałym kontakcie z Kościołem lokalnym ${ }^{21}$. Kongregacja odniosła się do dwóch sytuacji, w których instytuty powinny współpracować z Kościołem lokalnym. Dotyczy to likwidacji domu zakonnego lub dzieła prowadzonego przez instytut oraz alienacji dóbr kościelnych ${ }^{22}$.

\footnotetext{
${ }^{20}$ Zob. A. ZАмвоN, I beni ecclesiastici: amministrazione e vigilanza, Quaderni di Diritto ecclesiale 28 (2015), s. 202-229; F. G. Morrisey, Vatican Guidelines for the Administration of the Temporal Goods of Religious Institutes, w: The Temporal Goods of the Church. Selected Issues, red. S. Dubiel, P. Kaleta, London 2016, s. 185-207.

${ }^{21}$ Zob. J. Wroceński, Prawo Kościoła do posiadania i zarządzania majątkiem, w: Ars boni et aequi. Księga pamiątkowa dedykowana księdzu profesorowi Remigiuszowi Sobańskiemu z okazji osiemdziesiątej rocznicy urodzin, red. J. Wroceński, H. Pietrzak, Warszawa 2010, s. 582.

${ }^{22}$ Kongregacja Instytutów Życia Konsekrowanego i Stowarzyszeń Życia Apostolskiego 05.02.2005 opublikowała okólnik (Prot. Nr 971/2004) zaadresowany do wszystkich przełożonych generalnych na prawie papieskim, przypominając
} 
W przypadku decyzji o alienacji jakiegoś miejsca lub dzieła Kongregacja zaleca, aby wyższy przełożony zakonny poinformował o swoich zamiarach inne instytuty obecne na tym samym terenie tak, aby danego miasta lub diecezji nie pozbawić obecności zakonów.

Biorąc pod uwagę złożoność zagadnień ekonomicznych i finansowych w zarządzaniu dobrami i dziełami, Kongregacja wskazuje na konsultacje ze specjalistami, osobami świeckimi lub członkami innych instytutów. Niemniej jednak należy wystrzegać się dwóch skrajności: pierwsze to - rezygnowanie z porad konsultantów, by nie wydawać pieniędzy, natomiast drugie - trwonienie pieniędzy instytutu na zbędne konsultacje.

Warto przy tym pamiętać, że ostateczna odpowiedzialność za decyzje w kwestiach administracyjnych i ekonomicznych, dotyczących zarządzania spoczywa zawsze na instytucie (kan. 639 \$2) i nie może być przerzucona na osoby świeckie lub członków innych instytutów. Zadaniem konsultantów jest służyć pomocą, ale nie mogą oni zastąpić zarządu instytutem.

W związku z tym kontakty z konsultantami powinny być jasno określone za pomocą terminowych i klarownych umów, stosownie do świadczonych usług. Kongregacja podkreśla, że bardzo pomocne dla instytutu mogą być komisje specjalistyczne, z udziałem członków innych instytutów lub osób świeckich, i z takim regulaminem formalnym, który określa cele i czas trwania posługi członków komisji.

W ostatnim punkcie rozdziału II, Dykasteria odnosi się do kontaktów i współpracy z innymi instytutami ${ }^{23}$. Współpraca taka ma ogromne znaczenie we wspólnym działaniu duszpasterskim i charytatywnym w Kościołach partykularnych. Chodzi więc o jej umocnienie, tak, aby stała się bardziej zdecydowaną strategią kościelną.

o wymogu uzyskania opinii od biskupa diecezjalnego w przypadku alienacji dóbr instytutu. Renken, Church Property..., s. 353.

${ }^{23}$ Zob. Kongregacja DS. Instytutów Życia Konsekrowanego I Stowarzyszeń Życia Apostolskiego, Instrukcja. La collaborazione inter-istituti per la formazione (08 grudnia 1998), http://www.vatican.va/roman_curia/congregations/ ccscrlife/documents/rc_con_ccscrlife_doc_08121998_inter-formation_it.html [dostęp 01.06.2017]. 
Współpraca między instytutami zakonnymi (w zakresie dzielenia się dobrymi praktykami, pracy nad wspólnymi projektami, wprowadzania nowych metod służenia Kościołowi) jest podejmowana jako jeden ze sposobów na umocnienie administrowania i zarządzania zasobami oraz zwiększenie skuteczności misji każdego instytutu.

\section{Formacja w wymiarze ekonomicznym}

Ostatni rozdział Wytycznych ds. zarzadzania dobrami w instytutach $\dot{z} y c i a$ konsekrowanego $i$ w stowarzyszeniach $\dot{z} y c i a$ apostolskiego Kongregacja poświęca formacji w wymiarze ekonomicznym.

Zgodnie z kan. $636 \$ 1$, w każdym instytucie sprawy materialne powierzone są jednej osobie - ekonomowi, której przypisuje się funkcję techniczną ${ }^{24}$. Następstwem ustanowienia ekonoma czy to dla domu zakonnego, czy prowincji jest brak zainteresowania kwestiami ekonomicznymi wewnątrz wspólnot, przyczyniając się do braku wiedzy na temat kosztów życia i trudów związanych z zarządzaniem. Tego rodzaju zachowanie prowadzi do rozbieżności między ekonomią a misją. Co więcej, formacja ekonomów nie zawsze jest dostosowana do nowych potrzeb w rozumieniu zadań ekonoma. Dlatego Kongregacja kładzie nacisk na formację początkową, która powinna uwzględniać edukację w dziedzinie ekonomii i zarządzania, świadomości kosztów życia i prowadzenia misji, jak również uwrażliwiać na odpowiedzialne przeżywanie ślubu ubóstwa w kontekście obecnej sytuacji społeczno-gospodarczej. Formacja ekonomów powinna uwrażliwiać braci i siostry na zasady ewangeliczne, które są motorem działań ekonomicznych, i dostarczać praktycznych umiejętności umożliwiających pełnienie posługi ekonoma jako zarządzającego. Ekonomom należy pomagać i towarzyszyć w wypełnianiu ich roli, rozumianej jako służba, a nie władza, w byciu hojnymi i zapobiegliwymi, gdy chodzi o zapewnienie dostępności dóbr dla apostolstwa i misji.

\footnotetext{
${ }^{24}$ Zob. L. Chiappetta, Il codice di diritto canonico. Commento giuridico-pastorale, vol. 1, Bologna 2011, s. 777; zob. D.J. Andrés, El derecho de los religiosos..., s. 209.
} 


\section{Wnioski}

List okólny poświęcony wytycznym w zarządzaniu dobrami w instytutach życia konsekrowanego i stowarzyszeń życia apostolskiego został opublikowany w ważnym momencie historii Kościoła. Z jednej strony widać potrzebę zaplecza finansowego dla realizacji misji instytutu zgodnego z jego charyzmatem, a z drugiej dostrzec można wpływ pontyfikatu papieża Franciszka, który wielokrotnie nawoływał do przejrzystości i integralności w działalności finansowej Kościoła we wszystkich poziomach zarządzania.

Należy przyznać, że nie wszystkie podejmowane aspekty w liście okólnym są nowe - wiele z nich stanowi przypomnienie przepisów prawa kanonicznego, którymi powinni kierować się zarządcy dóbr kościelnych. Kongregacja podkreśla, że zarządzanie majątkiem w instytutach powinno być oparte na zasadzie ewangelicznej, aby akty zarządzania były dokonywane w pełnej przejrzystości. Postulat transparentności ma podnieść wiarygodność w realizacji misji instytutu. Innym, równie ważnym, zagadnieniem jest integralność finansów i kolegialność w podejmowaniu decyzji. W sytuacjach zawiłych Kongregacja radzi przełożonym, aby konsultowali się ze świeckimi specjalistami, oraz z innymi członkami instytutów.

Ciekawym spostrzeżeniem jest konstrukcja listu okólnego, który na wstępie i w zakończeniu Kongregacja odwołuje się do formacji w wymiarze ekonomicznym. Chodzi tu o to, aby członkowie instytutów byli świadomi kosztów życia, konsekwencji odpowiedzialni za dobra kościelne. Natomiast wybrani z nich ekonomowie, aby potrafili stawiać czoła nowym wyzwaniom w dziedzinie ekonomii i zarządzania.

\section{Guidelines of the Apostolic See for the administration of the goods in the Institutes of Consecrated Life and Societies of Apostolic Life}

The subject of this research concerns the circular letter of the Congregation for Institutes of Consecrated Life and Societies of Apostolic Life, entitled Guidelines for the Administration of goods in the Institutes of Consecrated 
Life and Societies of Apostolic Life. The Author highlights that the circular letter is a reflection of some of the difficulties encountered in administration and further sets some useful guidelines.

It is important to acknowledge that this information is not entirely new as there are many indicators of the usage of canon law, which should be adhered to by the administrators of ecclesiastical goods. The importance of management of goods belonging to religious institutes, lies in the transparency of financial reports as well as in the loyalty of the charism of the religious institute. The postulate of transparency is to increase the credibility of the mission of the institute. Another, equally important issue, is the financial integrity and collegiality to make a decision. Given the complexity of the financial issues the Congregation proposes a consultation with lay professionals, and other members of Institutes.

Interestingly, the beginning and the end of the circular letter refers to the formation in the economic dimension. The idea of this is to make members of religious institutes aware of the cost of living and their responsibility for ecclesiastical goods. It will also help those appointed stewards, to face new challenges in the field of economics and management.

SŁOWA KLUCZOWE: zarządzanie dobrami kościelnymi; transparentność; kolegialność; charyzmat zakonny

KEY WORDs: administration of ecclesiastical goods; transparency; collegiality; charism of the religious institute

\section{Nota o Autorze:}

Ks. DR Pawe Kaleta - adiunkt w Katedrze Norm Ogólnych i Kościelnego Prawa Majątkowego Wydziału Prawa, Prawa Kanonicznego i Administracji Katolickiego Uniwersytetu Lubelskiego Jana Pawła II. 